\title{
Neural Basis of Developing Salt Taste Sensation: Response Changes in Fetal, Postnatal, and Adult Sheep
}

\author{
CHARLOTTE M. MISTRETTA AND ROBERT M. BRADLEY \\ Department of Oral Biology, School of Dentistry, University of Michigan, \\ Ann Arbor, Michigan 48109
}

\begin{abstract}
To learn whether salt taste responses change during mammalian development, we recorded from multifiber preparations of the chorda tympani while stimulating the anterior tongue in sheep fetuses, lambs, and adults. Stimuli were $0.5 \mathrm{M} \mathrm{NH}_{4} \mathrm{Cl}, \mathrm{KCl}, \mathrm{NaCl}$, and $\mathrm{LiCl}$, and $0.05-0.75 \mathrm{M}$ concentration series of the first three salts. Ultrastructural studies were made of taste buds at different ages to determine whether morphological elements such as microvilli and tight junctions are present in young fetuses.

Substantial changes occur in relative salt taste responses, throughout development. In fetuses that are beginning the last third of gestation, $\mathrm{NaCl}$ and $\mathrm{LiCl}$ elicit much smaller response magnitudes than $\mathrm{NH}_{4} \mathrm{Cl}$ and $\mathrm{KCl}$. Throughout the rest of gestation and postnatally, the $\mathrm{NaCl}$ and $\mathrm{LiCl}$ responses gradually increase in magnitude relative to $\mathrm{NH}_{4} \mathrm{Cl}$ and $\mathrm{KCl}$. In adults, $\mathrm{NaCl}, \mathrm{LiCl}$, and $\mathrm{NH}_{4} \mathrm{Cl}$ all elicit similar response magnitudes and $\mathrm{KCl}$ is less effective as a taste stimulus. At ages when response ratios for the $0.5 \mathrm{M}$ salts are changing, there are no changes in shapes of the response/concentration functions for individual salts. Furthermore, microvilli are present on taste bud cell apices and tight junctions are found between cells in the youngest fetuses studied. Therefore, initial stimulus-receptor membrane contacts are probably similar to those in adults.

Our data suggest that different membrane components interact with the various monochloride salts and that taste receptors contain different proportions of these various membrane components at different developmental stages. Therefore young taste bud cells do not have the same salt response characteristics as mature cells, and a changing neural substrate underlies development of salt taste function, both pre- and postnatally.
\end{abstract}

Key words: taste, development, salt taste, chorda tympani, fetal taste

\begin{abstract}
We have observed a sequential appearance of specific response properties when recording from single taste neurons in the brainstem of sheep fetuses, lambs, and adults (Bradley and Mistretta, '80; Mistretta and Bradley, '77, '78). In young fetuses ( $<114$ days of gestation; term $=147$ days) responses were obtained during stimulation of the anterior tongue with two acids, citric and hydrochloric, and two salts, $\mathrm{NH}_{4} \mathrm{Cl}$ and $\mathrm{KCl}$. Two other monochloride salts, $\mathrm{NaCl}$ and $\mathrm{LiCl}$, were effective as stimuli only in older fetuses, lambs, and adults. We hypothesized that the emerging ability of the central taste system to respond to $\mathrm{NaCl}$ and $\mathrm{LiCl}$ was related to taste receptor maturation at cellular and/or molecular levels (Bradley and Mistretta, '80; Mistretta and Bradley, '78).

If the developmental acquisition of central neural responses to $\mathrm{NaCl}$ and $\mathrm{LiCl}$ does relate to maturation of taste
\end{abstract}

receptor properties, then studies of salt responses from the peripheral taste system should clarify possible underlying processes. We have, therefore, studied neurophysiological responses recorded from the chorda tympani, which innervates taste buds on the anterior two-thirds of the tongue, in fetal, postnatal, and adult sheep.

We recorded from the entire chorda tympani and from multifiber bundles to study the general response characteristics of a large population of taste buds. As taste stimuli, we selected the monochloride salts $\mathrm{NH}_{4} \mathrm{Cl}, \mathrm{KCl}, \mathrm{NaCl}$, and $\mathrm{LiCl}$ because: (1) Data have been collected in our laboratory on development of responses from sheep brainstem neurons (Bradley and Mistretta, ' 80 ) and from rat chorda

Accepted December 23, 1982. 
tympani and brainstem neurons (Ferrell et al., ' 81 ; Hill et al., '81, '82) to lingual stimulation with these chemicals; (2) these salts have been studied in adults of several species by other investigators (Beidler et al., '55); (3) a variety of mechanisms for salt taste transduction have been proposed (Beidler, '67; Beidler and Gross, '71; Brand and Bayley, '80; DeSimone and Price, '76; Kamo et al., '74; Mooser, '80); and (4) salt taste detection and recognition are critically important for the physiological maintenance of the organism (Dethier, '77).

In early studies from our laboratory, which emphasized responses to several taste stimuli in older sheep fetuses, we did not report developmental changes in salt responses (Bradley and Mistretta, '73). In contrast, we now demonstrate that the magnitudes of responses to four salts change in relation to one another during prenatal development and postnatally. Furthermore, we present ultrastructural descriptions of fetal taste buds that illustrate the presence of important cellular components early in gestation. Our observations suggest that the essential mechanism of salt taste stimulation does not change developmentally; rather, we propose that the composition of the taste membrane alters as it matures, so that relative changes occur in responses to various salts.

\section{METHODS}

\section{Animals and surgical preparation}

Sheep in five age groups were studied: (1) 110 days of gestation, included ten fetuses aged 108-114 days of gestation (term = 147 days); (2) 130 days of gestation, included seven fetuses aged 126-130 days; (3) perinatal, eight animals aged 142 days of gestation to 9 postnatal days; (4) lamb, nine lambs aged 35-85 days postnatally; (5) adult, eight adult ewes aged 2-4 years. Adults and lambs were anesthetized with an intravenous injection of sodium pentobarbital (30 mg/kg for adults; $20-25 \mathrm{mg} / \mathrm{kg}$ for lambs), tracheotomized, and given supplemental $\mathrm{O}_{2}(1.5-2.5$ liters $/$ minute). An indwelling catheter was placed in the jugular vein for subsequent anesthetic administration. Fetuses (anesthetized via the pregnant ewe) were delivered onto a table at the ewe's side and wrapped with a heating pad and absorbent cotton. The umbilical and placental circulation remained intact. Rectal temperature was continuously monitored.

\section{Electrophysiology}

The fetal, lamb, or adult head was secured in a metal, atraumatic holder and the mouth was dissected so that the anterior one-half of the tongue could be easily stimulated in a consistent manner. The exposed portion contained 90$95 \%$ of the total fungiform papillae on the ipsilateral half of the tongue.

The chorda tympani was dissected by a lateral approach through the cheek and ramus of the mandible. The nerve was cut central to the bifurcation of the chorda tympani and the lingual nerve, near the point at which the chorda tympani enters the tympanic bulla. Surrounding connective tissues were dissected from the nerve.

The sheep chorda tympani is composed of two or more small, discrete bundles of nerve fibers in older fetuses, lambs, and adults. Such fasciculi have been described in the adult sheep by Kitchell ('63). After recording from the whole chorda tympani, these bundles were dissected and recordings were made from separate bundles. Therefore, we ensured that responses from the entire nerve fiber population were sampled.
Either the whole chorda tympani or a discrete bundle of nerve fibers was placed on a platinum wire electrode, with a reference electrode positioned in nearby tissues. Neural activity was recorded with a preamplifier, oscilloscope, and audio monitor and then passed through a full-wave rectifier and smoothing circuit with a time constant of 0.5 seconds (Beidler, '53). This integrated neural activity was monitored with a rectilinear pen recorder. All neural data and voice cues were stored on magnetic tape for later analysis and photography.

\section{Stimuli}

Taste stimuli were $0.5 \mathrm{M}$ solutions of reagent grade $\mathrm{NH}_{4} \mathrm{Cl}, \mathrm{KCl}, \mathrm{NaCl}$, and $\mathrm{LiCl}$ dissolved in distilled water and maintained at room temperature. Concentrations of $0.5 \mathrm{M}$ were used because they elicit near-maximal responses for each of these salts in adults. Also, we knew that reproducible responses were obtained in animals from all age groups during repeated stimulation with $0.5 \mathrm{M}$ $\mathrm{NH}_{4} \mathrm{Cl}$ (Bradley and Mistretta, '73). The order of salt stimulation was varied during the experiment and one salt (either $\mathrm{NH}_{4} \mathrm{Cl}$ or $\mathrm{NaCl}$ ) was applied as every third or fourth stimulus to monitor response reproducibility. If responses to these repeated stimuli varied by more than $20 \%$, data were not included for analysis. All salts were usually applied at least twice. Responses to $0.05-0.75 \mathrm{M}$ concentration series of each salt were obtained when possible, also.

Twenty milliliters of each stimulus was applied to the anterior half of the tongue from syringes; the rest of the tongue remained in the mouth and was not exposed to stimuli. After 25-40 seconds the stimulus was rinsed from the tongue with $40-60 \mathrm{ml}$ of distilled water. At least $40 \mathrm{sec}-$ onds then elapsed before application of another stimulus. We chose not to use a flow chamber to stimulate the tongue in order to replicate conditions in our central nervous system studies (Bradley and Mistretta, '80). In the latter experiments we used the electrical stimulus artifact, which occurs when a chemical first contacts the tongue, to indicate stimulus onset for measures of single-unit response latency. Furthermore, we wanted to compare responses from the chorda tympani to taste responses from the glossopharyngeal nerve, which innervates taste buds in circumvallate papillae on the posterior tongue (Mistretta, '82). It is not feasible to design a flow chamber for stimulating the large field of circumvallate papillae on the lateral border of the posterior sheep tongue.

\section{Data analysis}

The integrated records of multifiber neural responses are typically composed of an initial phasic component that gradually adapts to a lower magnitude of neural response (Fig. 1). The magnitude of the phasic component is determined by stimulus application duration and rate (Marowitz and Halpern, '77; Smith and Bealer, '75), by responses to the tactile component of stimulus application, and by responses to the chemical stimulus per se. We measured responses at 20 seconds after stimulus onset, during the later, tonic or steady-state portion of the taste response. This enabled us to compare our results directly with published data on salt responses from adults of other species (Beidler et al., '55; Beidler, '61; Ferrell et al., '81; Hill and Almli, '80) and to exclude the part of the response related to variables other than taste.

Although measurement of the adapted part of the taste response is most useful for our analyses, some investiga- 

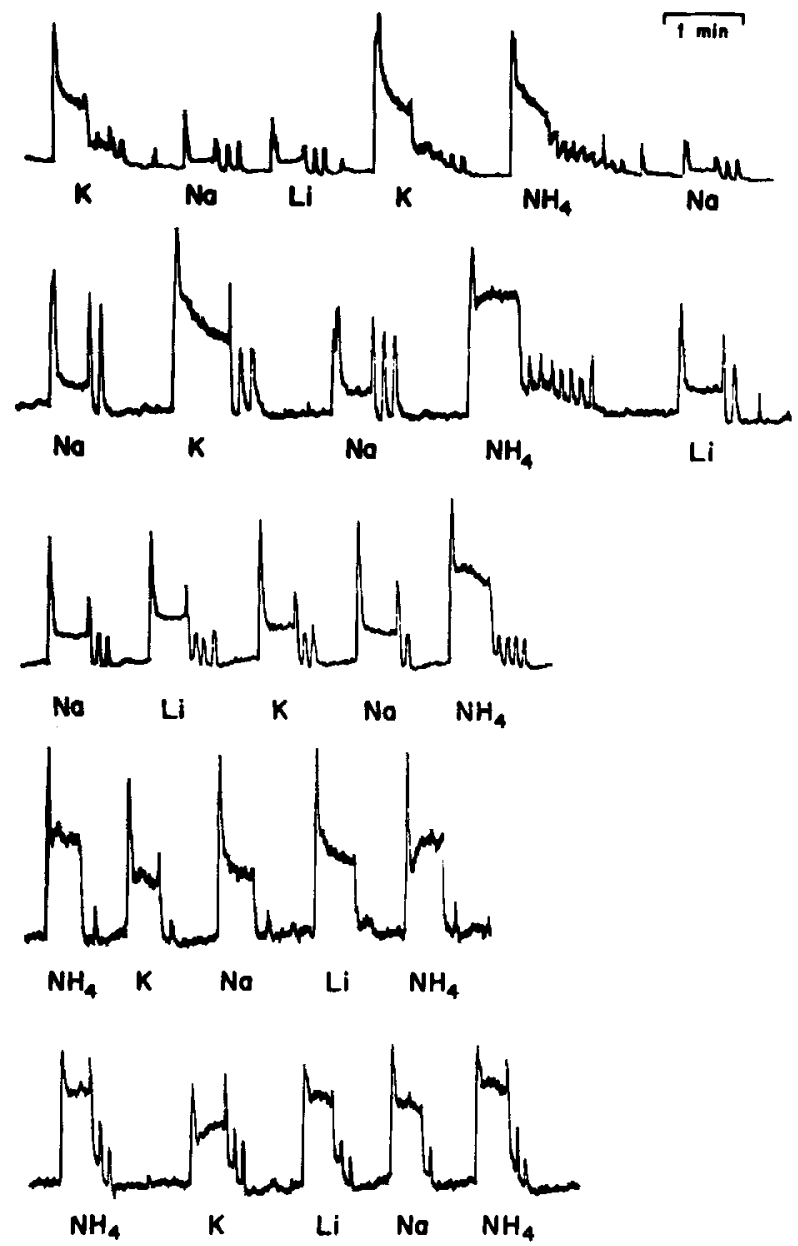

Fig. 1, Integrated records of multifiber responses from the chorda tympani in representative animals from each of five age groups. Chemical stimuli applied to the anterior tongue were $0.5 \mathrm{M} \mathrm{NH}_{4} \mathrm{Cl}, \mathrm{KCl}, \mathrm{NaCl}$, and $\mathrm{LiCl}$ On the right side of the figure the responses to $\mathrm{NH}_{4} \mathrm{Cl}$ and $\mathrm{NaCl}$ have been selected from the continuous recordings to emphasize the increasing $\mathrm{NaCl}$

tors have stressed the importance of studying the initial phasic component (Halpern and Marowitz, '73). Since animals can reportedly recognize some chemicals after stimulation of the tongue for only $168 \mathrm{msec}$ (Halpern and Tapper, '71), the early part of the neural response must contain information sufficient for some taste quality coding. Therefore we reanalyzed data from two age groups of sheep (110-day fetuses and postnatal lambs) on the basis of measures of the peak, transient response. Even though in our system the initial response included a tactile as well as taste component, the analysis of this component led to the same conclusions as analysis of the steady-state response. The order of effective stimulation for the salts was the same for each analysis in each age group, and the age-related changes for individual salts were in the same direction and of the same general magnitude. Therefore, by using measures of the later, adapted taste response we are not generating conclusions that would be invalid for the initial, transient response.

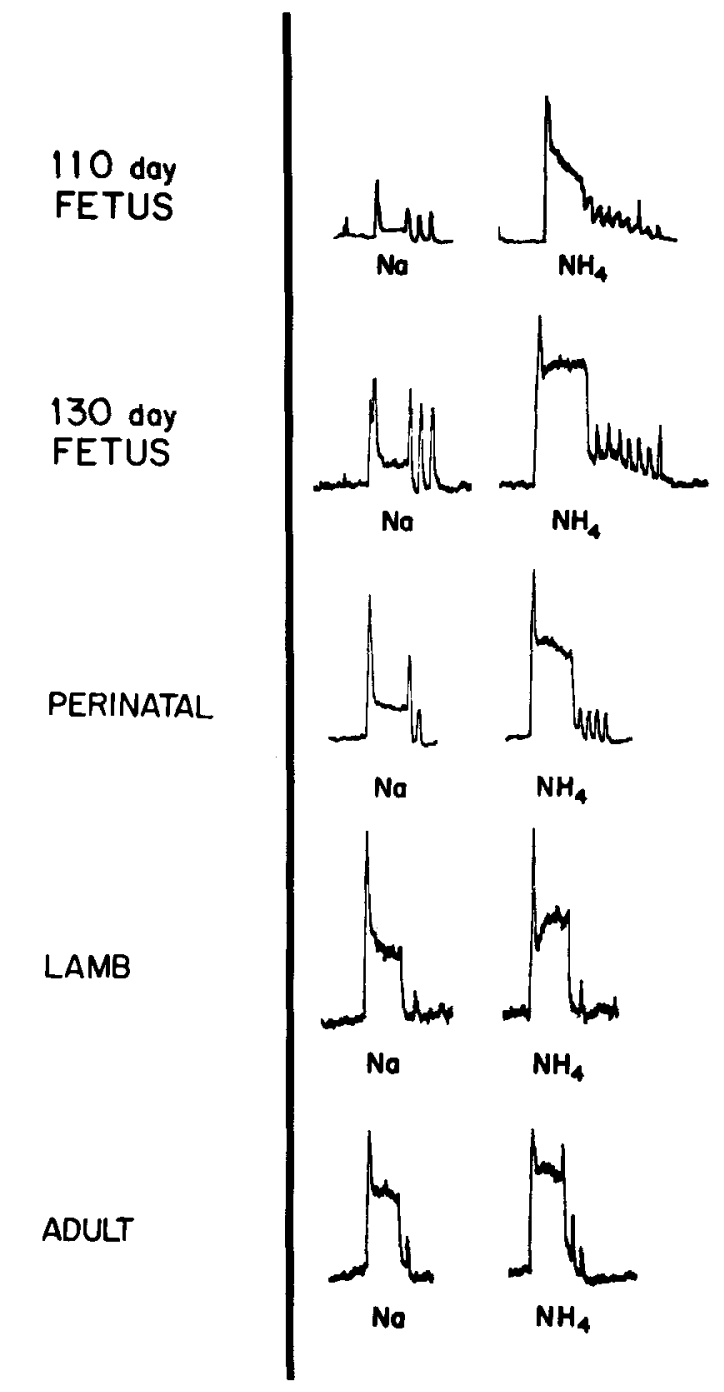

response during development, relative to $\mathrm{NH}_{4} \mathrm{Cl}$. For quantitative analysis of these data, the magnitude of each response was expressed as a ratio relative to the $\mathrm{NH}_{4} \mathrm{Cl}$ response. $\mathrm{NH}_{4} \mathrm{Cl}$ was used as the standard because it elicits a large-magnitude response throughout development.

Since one of our principal goals was to describe a possible change in taste response as a function of age, it was necessary to compare response magnitudes among different animals. Many variables other than age can affect the magnitude of the multifiber integrated response. Thus, as Beidler ('61) noted several years ago, it is not valid to make a direct comparison of absolute response values among animals, and the responses from any one animal must be carefully monitored with a standard chemical. For each animal, therefore, we calculated a ratio of every response relative to the standard $0.5 \mathrm{M} \mathrm{NH}_{4} \mathrm{Cl}$ response. A response equal to that elicited by stimulating the tongue with $0.5 \mathrm{M}$ $\mathrm{NH}_{4} \mathrm{Cl}$ would have a ratio of 1.00 . The choice of $\mathrm{NH}_{4} \mathrm{Cl}$ as a standard chemical in sheep is appropriate, since at all ages it elicits a large-magnitude neural response. Once ratios were calculated for each sheep, comparisons could be made among animals. When two or more separate multifiber bundles were studied in one animal, an average ratio for each salt was calculated. 


\section{Ultrastructure}

It is thought that apical extensions of taste bud cells, the microvilli, provide the point of initial contact between chemical stimulus and receptor in the taste pore (Beidler, '61). Therefore, to learn whether microvilli are present on taste bud cells in young fetuses, we used electron microscopy to study the fungiform papillae in four fetuses at 8090 days of gestation, six fetuses at 100-110 days, two lambs at 30-60 days postnatal, and one adult. The umbilical cord of anesthetized fetuses was clamped and fetuses were perfused via an intracardiac route with $2.5 \%$ phosphate-buffered glutaraldehyde. The tongue was removed and individual fungiform papillae were dissected for postfixation in $2 \%$ buffered osmium tetroxide. Papillae were embedded in Epon-Araldite and thin sections were cut and stained with toluidine blue to locate taste buds. Once a taste bud was located, serial sections were cut for electron microscopy. Ultrathin sections were stained with uranyl acetate and lead citrate.

\section{RESULTS Neurophysiology}

Integrated responses from one animal in each of the five age groups are presented in Figure 1. Several general response characteristics should be noticed. Initially, in 110and 130-day fetal groups, $\mathrm{NH}_{4} \mathrm{Cl}$ and $\mathrm{KCl}$ elicit taste responses of comparable magnitude; but gradually the responses to these salts become more disparate and in adults $\mathrm{NH}_{4} \mathrm{Cl}$ is a much more effective stimulus. $\mathrm{NaCl}$ and $\mathrm{LiCl}$ elicit responses of very similar magnitude throughout development, and therefore these salts will be considered together.

The relative ineffectiveness of $\mathrm{NaCl}$ and $\mathrm{LiCl}$ as stimuli in younger fetuses is apparent when they are compared to either $\mathrm{NH}_{4} \mathrm{Cl}$ or $\mathrm{KCl}$. In fetuses at about 110 days of gestation, $\mathrm{NaCl}$ and $\mathrm{LiCl}$ elicit integrated responses that barely exceed baseline. Progressively, though, the $\mathrm{NaCl}$ and $\mathrm{LiCl}$ response magnitudes increase during development. To emphasize the extent of this change, individual responses to $\mathrm{NaCl}$ and $\mathrm{NH}_{4} \mathrm{Cl}$ (the standard stimulus) are compared on the right side of Figure 1. The striking increase in effectiveness of $\mathrm{NaCl}$ (and $\mathrm{LiCl}$ ) relative to $\mathrm{NH}_{4} \mathrm{Cl}$ continues even after birth, as is apparent from the perinatal and adult responses.

To quantify these changes in salt taste sensation, the average ratios of responses to each salt, relative to the $\mathrm{NH}_{4} \mathrm{Cl}$ response, were plotted for the five age groups (Fig. 2). The extent of changes was studied with analysis of variance. Overall, there is a general increase in the relative stimulating effectiveness of $\mathrm{NaCl}(\mathrm{F}(4,41)=21.77, P<$ $.0001)$ and $\operatorname{LiCl}(\mathrm{F}(4,41)=19.40, P<.0001)$ during development. To learn whether differences in ratios between individual age groups were significant, pairwise comparisons were calculated (Scheffé multiple comparison allowances). All comparisons were significantly different $(P<$ .05) except: $\mathrm{NaCl}$ at 110 days vs. 130 days, and 130 days vs. perinatal; and $\mathrm{LiCl}$ at 130 days vs. perinatal ratios. Therefore, changes occur in taste responses to $\mathrm{NaCl}$ and $\mathrm{LiCl}$, relative to $\mathrm{NH}_{4} \mathrm{Cl}$, during prenatal and postnatal development. From 110 days of gestation to birth, the $\mathrm{NaCl} /$ $\mathrm{NH}_{4} \mathrm{Cl}$ response ratio nearly doubles from 0.22 to 0.41 . Furthermore, the remarkable degree of the postnatal component is made apparent by integrated recordings from an individual ewe and her 35-day lamb (Fig. 3). For this lamb,

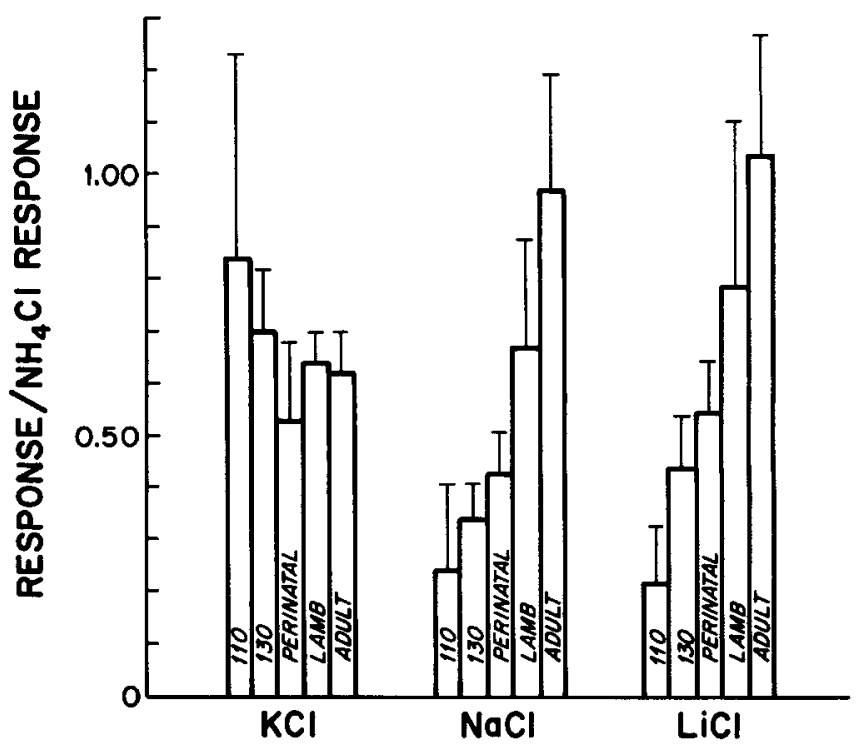

Fig. 2. Mean response ratios and standard deviations for $\mathrm{KCl}, \mathrm{NaCl}$, and $\mathrm{LiCl}$ relative to $\mathrm{NH}_{4} \mathrm{Cl}$ in five age groups: ten fetuses at about 110 days of gestation, seven at about 130 days of gestation, eight perinatal lambs just before or after birth, nine postnatal lambs, and eight adults. For each salt, a response equal in magnitude to that elicited by $\mathrm{NH}_{4} \mathrm{Cl}$ yields a ratio of $1.00 . \mathrm{NaCl}$ and $\mathrm{LiCl}$ increase in stimulating effectiveness throughout development, both pre- and postnatally. $\mathrm{KCl}$, however, decreases in stimulating effectiveness, but the change is prenatal only; after birth the $\mathrm{KCl}$ / $\mathrm{NH} \triangleleft \mathrm{Cl}$ ratio remains constant.

\section{5 day lamb}

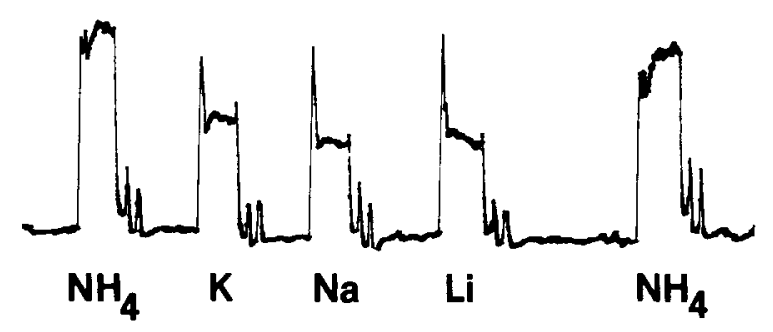

\section{3 year adult}

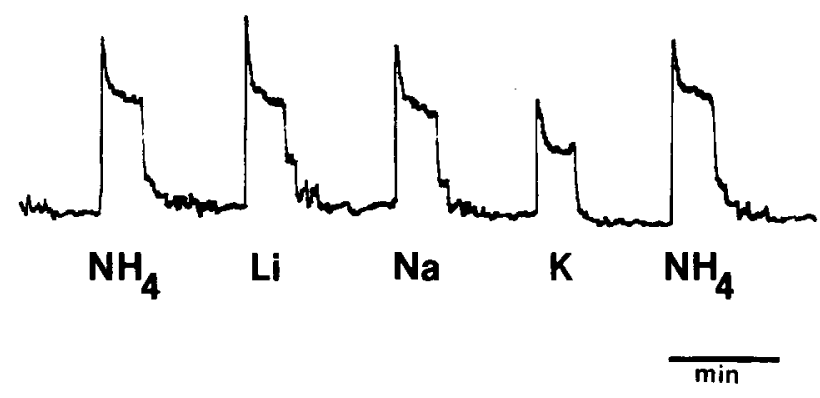

Fig. 3. Integrated records of multifiber responses from the chorda tympani in an adult ewe and her lamb. Changes in the relative response magnitudes for $\mathrm{NaCl}$ and $\mathrm{LiCl}$ continue postnatally. 
the $\mathrm{NaCl} / \mathrm{NH}_{4} \mathrm{Cl}$ ratio was 0.50 , compared to 0.82 in the ewe.

Responses to $\mathrm{KCl}$ also alter as a function of age $(\mathrm{F}(4,41)$ $=2.56, P<.05$ ). However, the change contrasts with that of $\mathrm{NaCl}$ and $\mathrm{LiCl}$ because: (1) $\mathrm{KCl}$ decreases in effectiveness relative to $\mathrm{NH}_{4} \mathrm{Cl}$ (Fig. 2); (2) the overall decrease in stimulating effectiveness is smaller than the relative increase for $\mathrm{NaCl}$ and $\mathrm{LiCl}$; and (3) the change occurs prenaally only. Using pairwise comparisons we found that the ratio for 110-day fetuses differs from those for perinatal, lamb, and adult groups $(P<.05)$, but no other groups differ from each other. Therefore, after birth the $\mathrm{KCl} / \mathrm{NH}_{4} \mathrm{Cl}$ response ratio remains constant.

We conclude that there are substantial changes in $\mathrm{NaCl}$, $\mathrm{LiCl}$, and $\mathrm{KCl}$ responses, relative to $\mathrm{NH}_{4} \mathrm{Cl}$, during the last 40 days of gestation. In addition, postnatal changes occur in $\mathrm{NaCl}$ and $\mathrm{LiCl}$ responses. These alterations are so large that they result in an actual reversal of the order of stimulating effectiveness for some of the monochloride salts. $\mathrm{NaCl}$ and $\mathrm{LiCl}$ are the least effective salts and $\mathrm{KCl}$ is second in effectiveness in 110-day fetuses (Fig. 4); in adults, $\mathrm{NaCl}$ and $\mathrm{LiCl}$ have displaced $\mathrm{KCl}$ and elicit responses equal in magnitude to those for $\mathrm{NH}_{4} \mathrm{Cl}$.

In order to learn whether there are obvious developmental alterations in taste responses to a range of concentrations, neural activity was studied during stimulation of the tongue with series of $0.05-0.75 \mathrm{M} \mathrm{NH}_{4} \mathrm{Cl}$ (perinatal, lamb, and adult groups), $\mathrm{KCl}$, and $\mathrm{NaCl}$ (perinatal and lamb groups) (Fig. 5). The functions illustrated in Figure 5 indicate that the shape of the response/concentration curve for a specific salt does not change during development. We replotted responses as a function of log concentration (Fig. 5) and used analysis of covariance to learn whether these functions are indeed parallel at different ages. For each salt, analysis demonstrated that there is no change in slope of the functions across these ages $\left(\mathrm{NH}_{4} \mathrm{Cl}\right.$ : $\mathrm{F}(2,66)=1.04, P=0.36 ; \mathrm{KCl}: \mathrm{F}(1,41)=1.39, P=0.24$; $\mathrm{NaCl}: \mathrm{F}(1,39)=0.18, P=0.67)$. Therefore, at ages when relative response ratios for the $0.5 \mathrm{M}$ salts are changing, there is no difference in shapes of the response/concentration functions.

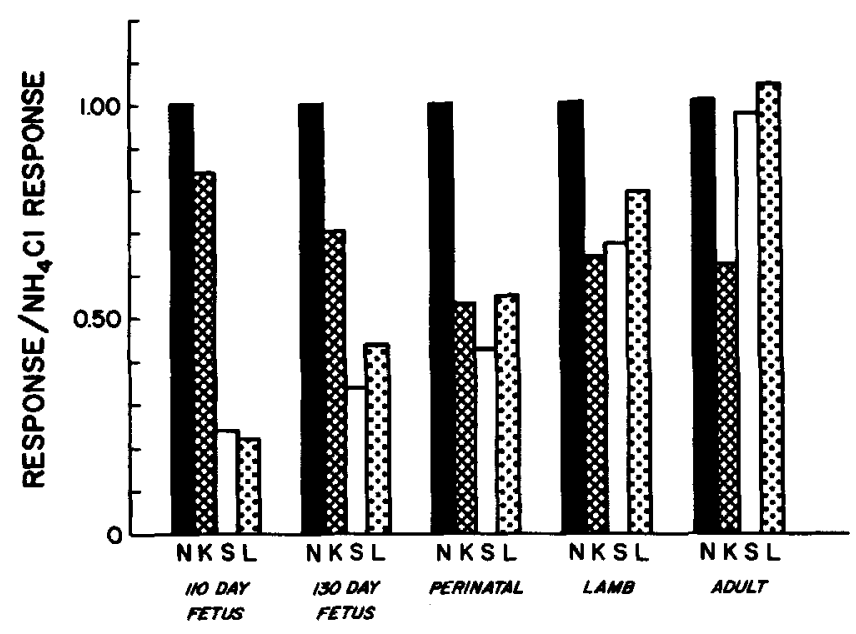

Fig. 4. Mean response ratios for $\mathrm{KCl}(\mathrm{K}), \mathrm{NaCl}(\mathrm{S})$, and $\mathrm{LiCl}(\mathrm{L})$, relative to $\mathrm{NH}_{4} \mathrm{Cl}(\mathrm{N})$, replotted from Figure 2 to illustrate developmental changes in the order of stimulating effectiveness. $\mathrm{NaCl}$ and $\mathrm{LiCl}$ progress from least effective stimuli in fetuses to rank equally as effective as $\mathrm{NH}_{4} \mathrm{Cl}$ in adults.

\section{Ultrastructure}

The electrophysiological data demonstrate that developmental changes in taste sensation occur over essentially the entire life cycle in sheep. Therefore, alterations in taste function do not relate simply to the early morphological events of taste bud formation. However, since it is generally considered that the initial steps in the taste transduction process occur in the membranes of taste bud microvilli (Beidler, '61), it is essential to know whether these apical, cellular extensions are present in young fetuses.

From light microscopic studies we had previously observed that structurally immature taste buds are present on the anterior tongue by 50 days of gestation in fetal sheep (Bradley and Mistretta, '72, '73). The ultrastructural investigations we report here demonstrate that by at least 80 days of gestation a number of important structural components are present in the taste bud. For example, the apices of taste bud cells are specialized in short microvilli and club-shaped processes (Fig. 6A-C) similar to those described in the adult rabbit (Jahnke and Bauer, 79). Between the apices of the taste bud cells, and between taste bud and surrounding epithelial cells, are membrane specializations that have been characterized in freeze-fracture studies by Jahnke and Bauer ('79) as tight functions (Fig. $6 \mathrm{~A}-\mathrm{C}$ ). Below the tight junctions, desmosomes are present (Fig. 6C). The presence of tight junctions in adult mammals has been interpreted as providing a barrier to entrance of stimuli from the oral cavity into the intercellular spaces of the taste bud (Farbman, '65a). Although the tight junction is clearly important in the physiology of transport across tissues, the actual barrier provided against diffusion can vary from "tight" to "leaky" (Macknight and Leader, '81) and the correlation between tight junction morphology and epithelial tightness is reportedly poor (Mollgard and Rostgaard, '81). However, although conclusions about a specific role for these junctions in epithelial diffusion at any age cannot be drawn, their presence in young fetuses is one other indicator of the degree of maturation of the taste bud.

Not only are apical specializations of taste bud cells and tight junctions found in taste buds at 80 days of gestation, but also at least two morphological cell types (I and II) are present (Fig. 6C). In most cells the nucleus has a dense appearance and the cytoplasm contains dark granules; these are termed dark cells, or type I in Murray's classification (Murray, '73). The nuclei of a smaller number of cells are less dense in appearance, and these cells do not have dense cytoplasmic granules. These are termed light cells, or type II.

Numerous nerve profiles are present in the fetal taste bud at 80-90 days of gestation (Fig. 7). They are distributed throughout the bud and may be found near the taste pit region. We cannot comment on the developmental sig. nificance of such profiles in sheep taste buds without a quantitative study that includes several age groups. The presence of such profiles at 80-90 days of gestation, however, is another indication of general structural maturity.

The structural characteristics of the fetal sheep taste bud at 100-110 days of gestation are similar to those at 80-90 days. Although we have not quantified observations in serial sections, we have the definite impression that club-shaped apical processes and microvilli have increased in length (Fig. 8). This presumably increases the area of accessible membrane available for initial interaction with chemical stimuli. 

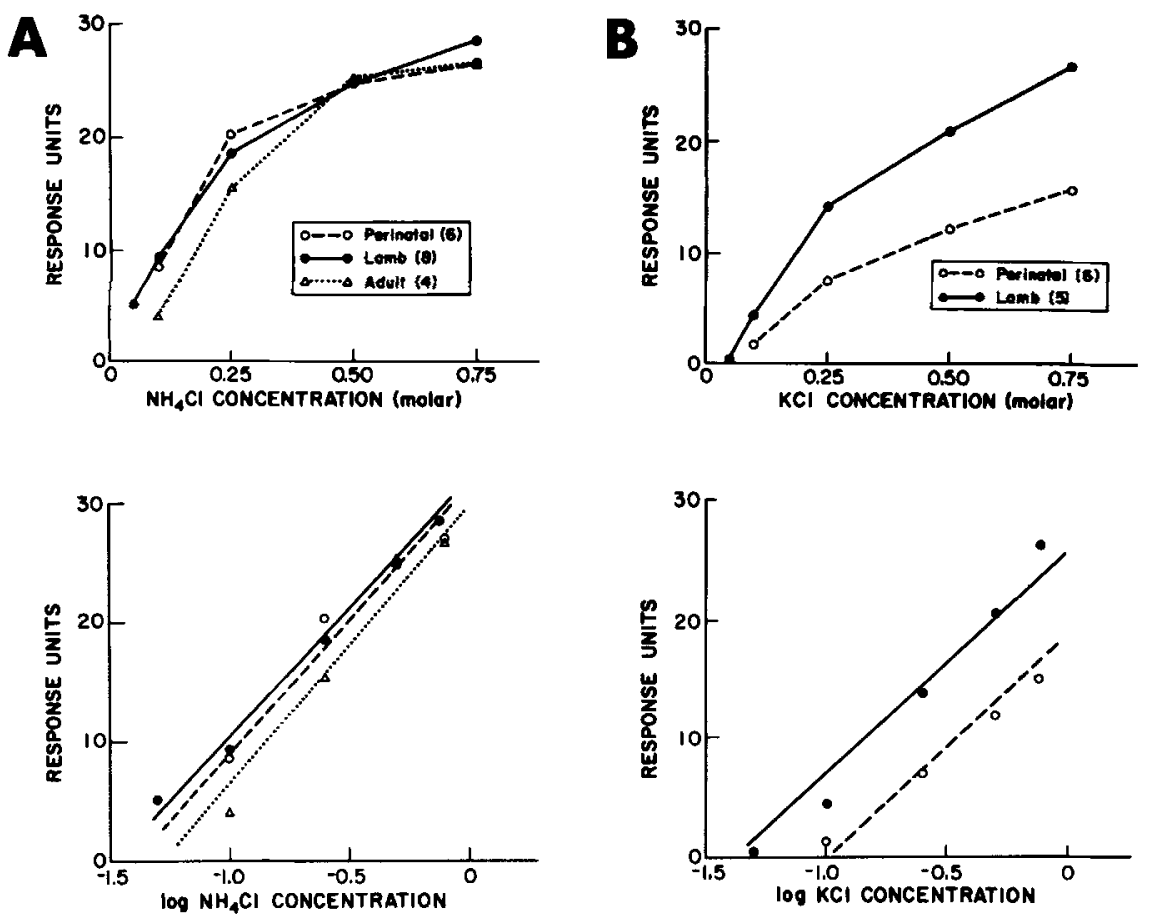
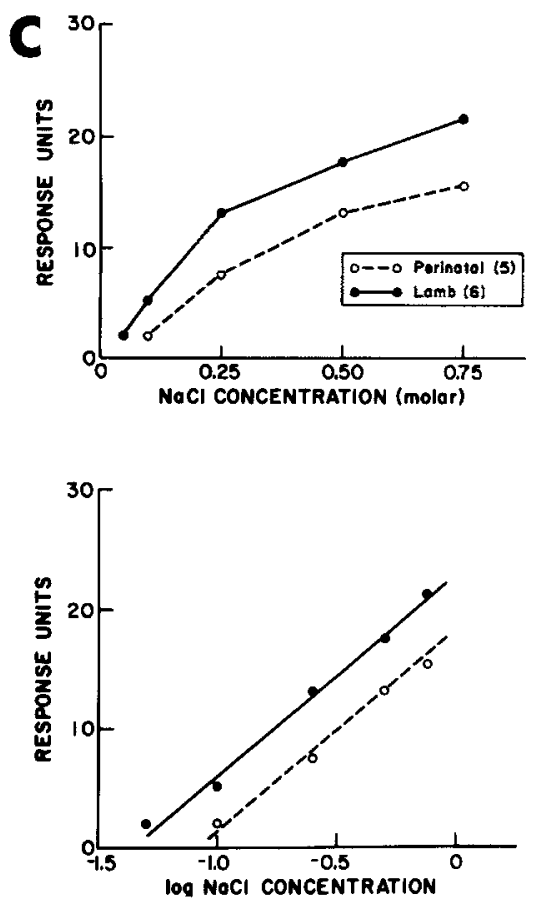

Fig. 5. Average responses to concentration series of $\mathrm{NH}_{4} \mathrm{Cl}(\mathrm{A}), \mathrm{KCl}(\mathrm{B})$, and $\mathrm{NaCl}(\mathrm{C})$, in animals from perinatal, lamb, and adult $\left(\mathrm{NH}_{4} \mathrm{Cl}\right)$ age groups. The number of response/concentration functions studied at each age is noted in parentheses in the legends. From the direct, linear plots it appears that the shapes of these functions for an individual salt do not change with age. Semilog plots of the functions were made, which were then compared with analysis of covariance. For each salt, the functions from different age groups are parallel.
During the rest of gestation and postnatally, increasing layers of cornified cells are added on the surface of the sheep fungiform papillae (Bradley and Mistretta, '72). Therefore the taste pit region becomes more defined and communicates with the oral environment via a narrow taste pore (Fig. 9). Furthermore, the pit is now filled with a densely staining, homogeneous material that surrounds the microvilli. We have not yet determined when this substance first appears during development nor is there information on its chemical composition.

In summary, electron microscopic observations have demonstrated that early fetal taste buds have apical cellular extensions and microvilli, intercellular tight junctions, and diverse cell types. These characteristics are present from at least 80 days of gestation. Therefore the electrophysiological responses from 110-day fetuses are mediated by taste buds that already possess several structural features characteristic of mature taste buds.

\section{DISCUSSION}

During development there are changes in neurophysiological salt responses from the primary afferents that innervate taste receptors on the anterior tongue. In fetuses that are beginning the last third of gestation, $\mathrm{NaCl}$ and $\mathrm{LiCl}$ elicit much smaller response magnitudes from the chorda tympani than $\mathrm{NH}_{4} \mathrm{Cl}$ and $\mathrm{KCl}$. Throughout the rest of gestation and postnatally, the $\mathrm{NaCl}$ and $\mathrm{LiCl}$ responses gradually increase in magnitude relative to $\mathrm{NH}_{4} \mathrm{Cl}$ and $\mathrm{KCl}$. Finally, in adulthood, $\mathrm{NaCl}, \mathrm{LiCl}$, and $\mathrm{NH}_{4} \mathrm{Cl}$ all elicit similar response magnitudes and $\mathrm{KCl}$ is relatively less effective as a taste stimulus. Although in our first study of taste responses from the fetal chorda tympani (Bradley and Mistretta, 73) we reported that salt responses in fetuses were similar to those in lambs and adults, we now know that distinct differences exist among age groups. We have been able to discern these developmental changes by quantifying chorda tympani responses as ratios and comparing average ratios across ages, and by recording from a larger number of younger fetuses, lambs, and adults.

The developmental changes are so substantial that it could be hypothesized that the monochloride salts are stimulating early fetal receptors via a different mechanism than in adults - for example, by penetrating into the taste bud and interacting directly with nerve processes. However, three types of evidence suggest that the essential stimulating mechanism is not different in fetuses.

First, from ultrastructural observations, it is apparent that well-developed microvilli and other apical, cellular extensions are present in fetal taste buds by 80 days of gestation ( 30 days before the age at which we began chorda tympani recordings). Therefore apical specializations are present to provide an initial region for stimulus-taste bud interactions, as in adults (Beidler, '61; Murray, '73). Also, tight junctions are present between the apices of taste bud cells and between taste bud and surrounding epithelial cells; such junctions should prevent direct penetration of chemicals into the bud (Farbman, '65a; Murray, '73). There is no reason, therefore, to assume that initial stimulustaste bud interactions are substantially different at the developmental ages we have studied. Taste stimulation in young fetuses is probably via interaction with microvilli membranes, as in adults (Bradley et al., '80). Interestingly, microvilli are present in the pore region of rat taste buds by 7 days after birth (Farbman, '65b), yet in older rats (12- 


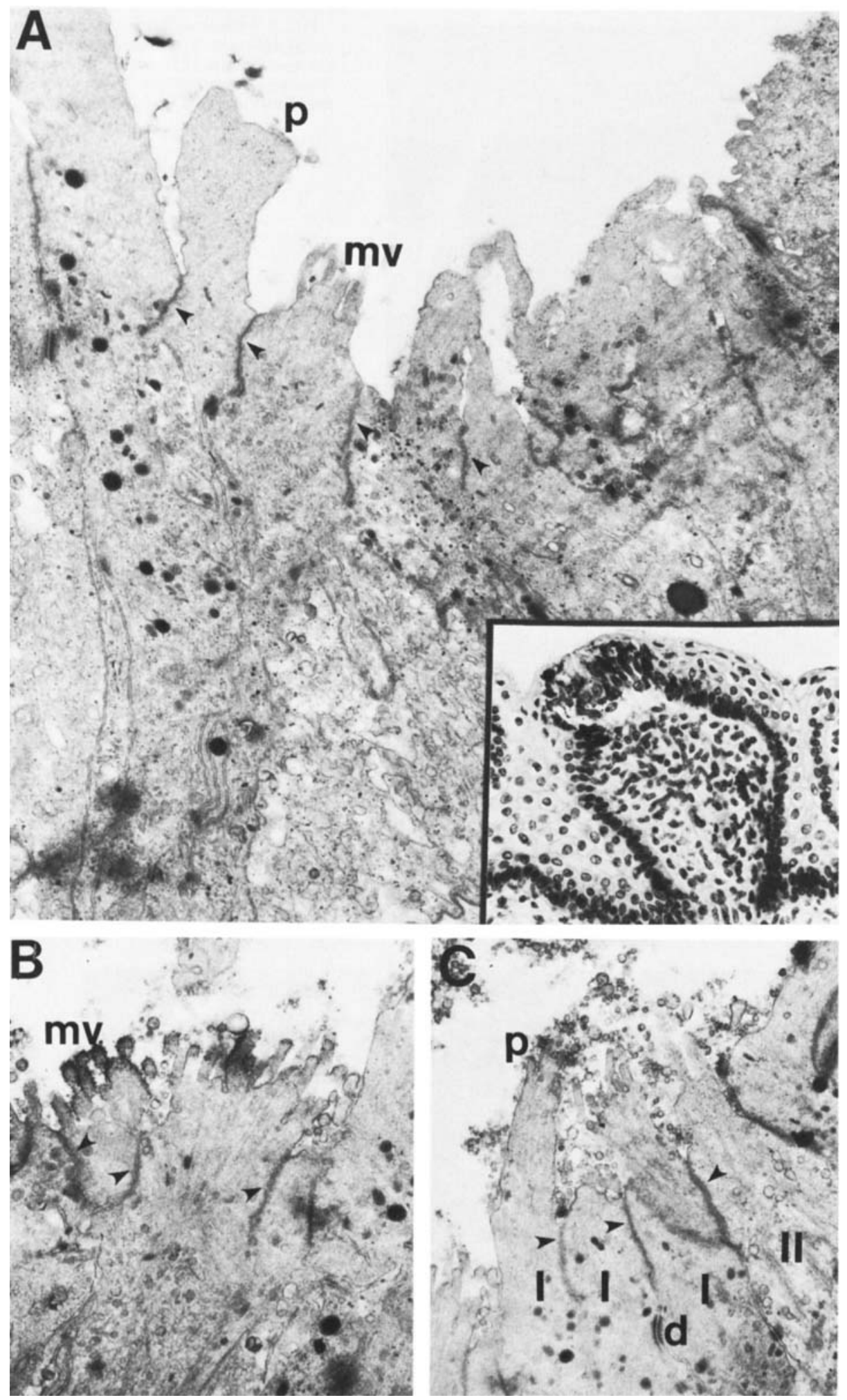

Fig. 6. Electron micrographs of the apical portions of cells in the pit region of three taste buds from fetuses aged 80 days of gestation $(\times 20,000, \times 22,000, X$ 22,000 ). The inset is a light micrograph of a taste bud and fungiform papilla from an 80 -day fetus $(\times 250)$. The cells terminate in short microvilli (mv) or blunt, clubshaped processes (p). All cell apices are joined by tight junctions (arrowheads). Below these junctions, desmosomes (d) are often seen, and at least two cell types, I and II in Murray's classification, are already present at this age $(6 \mathrm{C})$.

60 days postnatal) substantial changes occur in neurophysiological taste responses (Ferrell et al., ' 81 ; Hill and Almli, '80; Hill et al., '82).

Other evidence derives from study of neurophysiological response characteristics in young fetuses (Fig. 1). All re- sponses have a very rapid rise time after stimulation and a rapid decay to baseline levels after rinsing. Furthermore, chemicals at relatively high concentrations can be repeatedly applied to the tongue without receptor destruction, i.e., without loss of response magnitude. All of these char- 


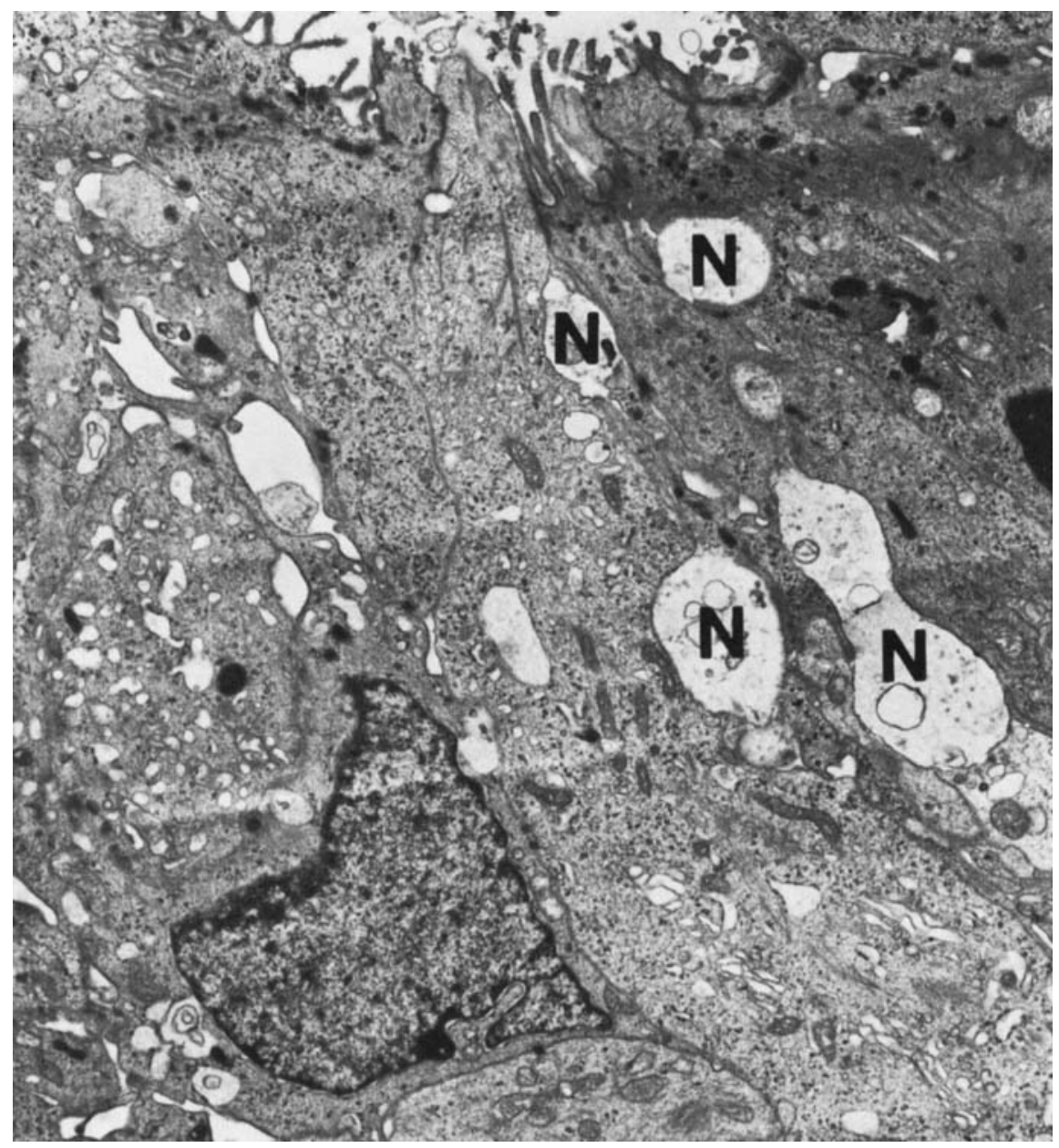

Fig. 7. Electron micrograph of the apical one-third of a taste bud from a fetus aged 90 days of gestation $(\times 10,000)$ Numerous nerve profiles $(\mathrm{N})$ are present. sometimes situated near the pit region.

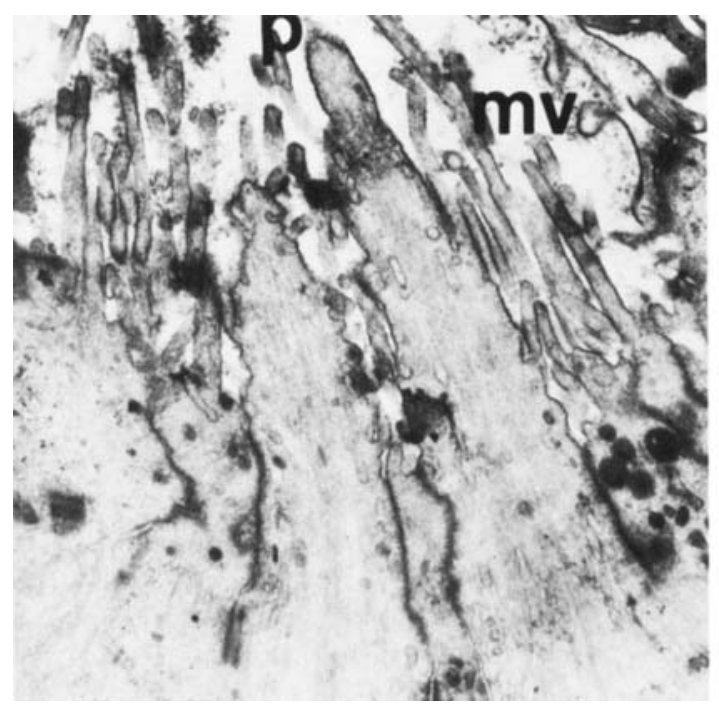

Fig. 8. Electron micrographs of the apical regions of two taste buds from fetuses aged 100 days of gestation $(\times 20,000)$. A light micrograph from a 110-day fetus is included as an inset $(\times 150)$. Club-shaped processes

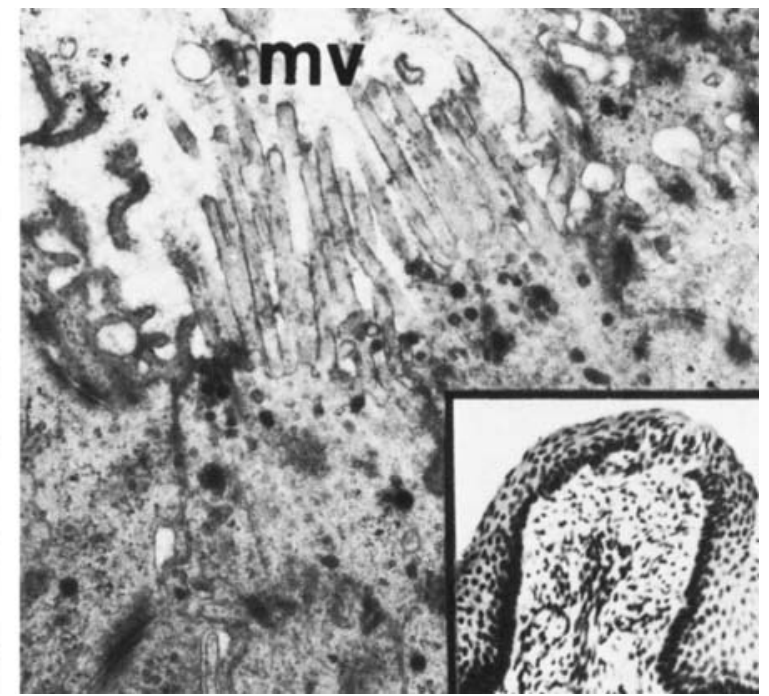

(p) and microvilli (mv) are present at the cell apices. The microvilli have apparently increased in length when compared to taste bud cells in 80-day fetuses. 


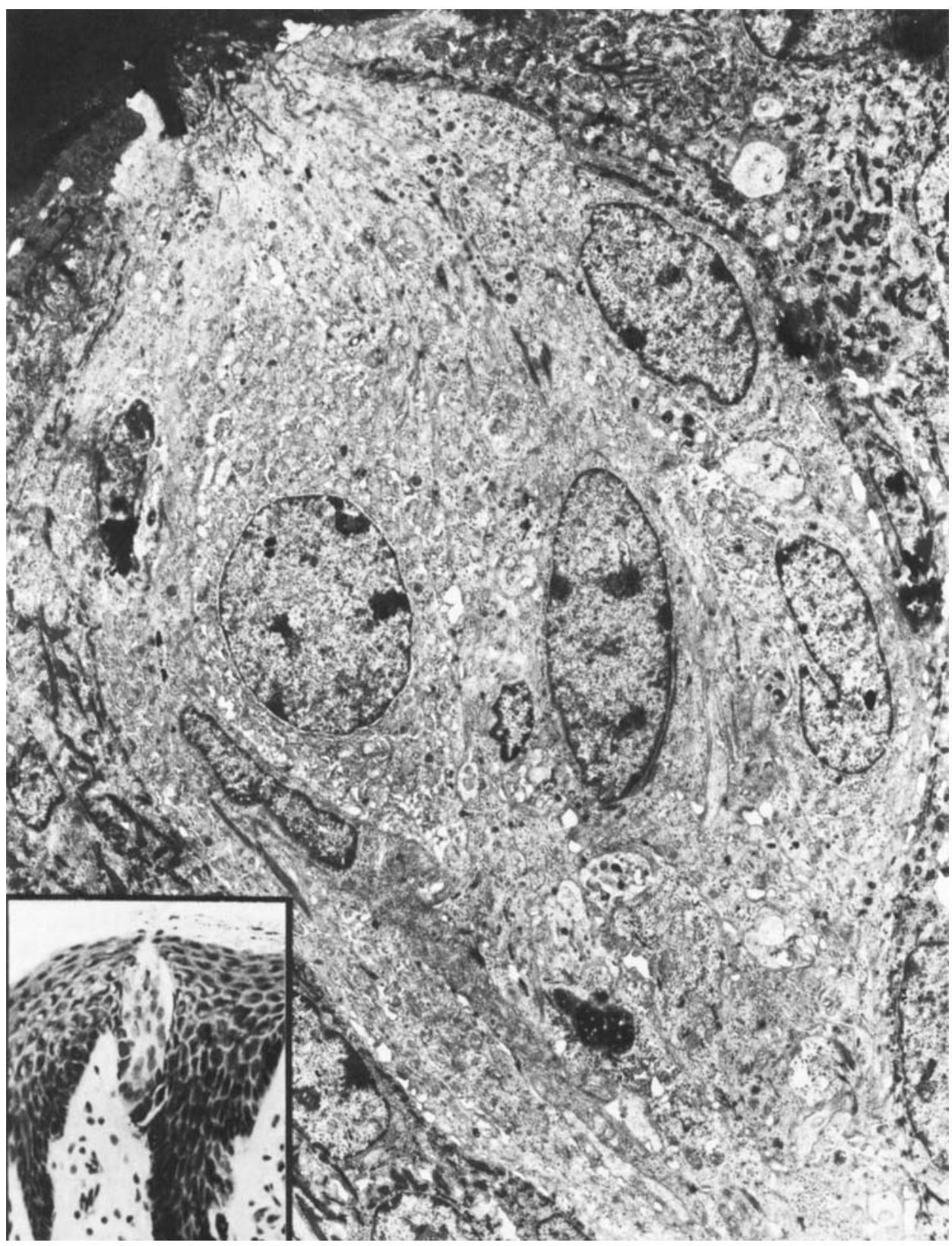

Fig. 9. Electron micrograph of the taste bud from a lamb aged 64 days after birth $(\times 1,500)$ with a light micrograph inset of an adult taste bud $(\times 200)$. The taste pit region is filled with a densely staining material, and a narrow pore or channel now provides communication between taste bud cells and the oral environment.

acteristics are typical of multifiber responses in adults and therefore suggest that similar stimulating mechanisms are operating.

Finally, evidence is obtained from response/concentration functions also. The shapes of these functions do not alter at ages when the response ratios for $0.5 \mathrm{M}$ salts are changing. If highly different stimulation mechanisms were involved in these age groups, one would predict differences in the concentrations at which these curves begin to decelerate or asymptote and in the slopes of the initial segments of the curves.

Thus, from data on ultrastructure and neurophysiological responses of fetal taste buds, we conclude that there is no compelling reason to propose different stimulating mechanisms in young fetuses from those in adult sheep.

\section{Proposed changes in taste receptor membranes}

If there are no apparent changes in basic stimulus-receptor interactions for the monochloride salts, then why do relative salt taste response magnitudes alter during development? We suggest that (1) our data support the proposition that different membrane components interact with the various monochloride salts (Beidler, '61; Beidler and Gross, '71) and that (2) taste receptors contain different proportions of these various membrane components at different developmental stages.

With respect to the first proposal, it is important to remember that $\mathrm{NaCl}$ and $\mathrm{LiCl}$ become more effective taste stimuli than $\mathrm{NH}_{4} \mathrm{Cl}$, throughout development. However, responses to $\mathrm{KCl}$ are characterized by a different developmental trend. Rather than a gradual increase in stimu- 
lating effectiveness relative to the $\mathrm{NH}_{4} \mathrm{Cl}$ standard, $\mathrm{KCl}$ elicits taste responses from the chorda tympani nerve that decrease in magnitude during the last third of gestation. After birth, $\mathrm{KCl}$ response magnitudes remain relatively constant.

Thus, $\mathrm{KCl}$ responses decrease when $\mathrm{NaCl}$ and $\mathrm{LiCl}$ responses increase. In addition, $\mathrm{KCl}$ responses are maintained at a constant relative magnitude during postnatal development when $\mathrm{NaCl}$ and $\mathrm{LiCl}$ responses are still changing. Assuming that the stimulus acts at the level of the receptor cell membrane in the initial events of taste reception and that the monochloride salts have equal access to the membrane, it seems that the same set of membrane components cannot be interacting with these salts. Others also have proposed that different types of "sites" exist on the surface of the taste cell which respond differentially to various cations (Beidler, '61; Beidler and Gross, '71).

However, the specific receptor components which are in fact involved in taste membrane discrimination among the monovalent cations $\mathrm{Na}^{+}, \mathrm{Li}^{+}, \mathrm{K}^{+}$, and $\mathrm{NH}_{4}{ }^{+}$are clearly not known. Salt taste mechanisms are currently the subject of extensive investigation (Cagan and Kare, '81; Kare et al., '80). It has been proposed that salt discrimination is determined by free energy changes that occur when hydrated cations interact with membrane negative charges in different molecular environments (Diamond and Wright, '69). A carboxyl or phosphate group in one physicochemical environment may react with sodium more effectively than potassium; carboxyl or phosphate in another environment may display reverse affinities. Charged groups in membrane phospholipids or proteins, situated in different molecular environments and with different molecular orientations, should respond differentially to various cations (Beidler and Gross, '71; Brand and Bayley, '80; DeSimone and Heck, '80; Kamo et al., '74). Recently a role for $\mathrm{Na}^{+}$ transport has also been proposed in early taste transduction events (DeSimone et al., '81; Sato and Beidler, '75; Sato et al., ' 82 ).

To account for developmental changes in the magnitude of salt taste responses, we predict that taste receptors contain different proportions of various cation-responsive membrane components at different developmental stages. During development, the taste membrane might acquire an increasing proportion of available negative charges in a particular molecular setting that renders these charges more responsive to $\mathrm{Na}^{+}$and $\mathrm{Li}^{+}$than to $\mathrm{NH}_{4}{ }^{+}$or $\mathrm{K}^{+}$. This increasing proportion of $\mathrm{Na}^{+}$-responsive components could be acquired through different geometric configurations of the same receptor molecules in the membrane at different ages. Alternatively, different receptor molecules may be present at various developmental stages or channels for ion transport may be added or altered.

Evidence to support the proposal that membrane components highly responsive to $\mathrm{Na}^{+}$may be added during development is provided by studies in rat. Changes in whole nerve taste responses occur postnatally in the rat similar to those that take place pre- and postnatally in sheep (Ferrell et al., '81; Hill and Almli, '80). In single fiber studies in rat it has now been observed that there are developmental increase in response frequencies to $\mathrm{NaCl}$ and $\mathrm{LiCl}$ while frequencies to $\mathrm{NH}_{4} \mathrm{Cl}$ remain constant (Hill et al., '82). Furthermore, the proportion of fibers that respond maximally to $\mathrm{NaCl}$ and $\mathrm{LiCl}$ more than doubles from early postnatal life to adulthood, whereas the proportion responding maximally to $\mathrm{NH}_{4} \mathrm{Cl}$ decreases. These single-unit studies indi- cate that salt receptor components alter in relative proportions during development, and they suggest that in the rat more $\mathrm{Na}^{+}$-responsive components may be added relative to $\mathrm{NH}_{4}{ }^{+}$-responsive components.

Finally, one or all of the cations we have studied might interact with more than one receptor "component" or "site" on the taste cell membrane. In the adult rat $\mathrm{NH}_{4}^{+}$and $\mathrm{K}^{+}$ presumably interact with two different, independent sets of sites, whereas $\mathrm{Na}^{+}$and $\mathrm{Li}^{+}$interact with one set of sites (Beidler, '61). The two sites for $\mathrm{NH}_{4}^{+}$and $\mathrm{K}^{+}$have very different binding constants, so that for each salt there is a group of sites that binds very strongly compared to the other, more weakly binding group. If more than one set of receptor components for any of the cations also occurs in sheep, then proportions of various sets of sites may alter during development, or the binding affinity for one set of sites may change. The idea of more than one set of membrane components interacting with $\mathrm{NH}_{4} \mathrm{Cl}$ and $\mathrm{KCl}$ is supported by knowledge that these salts elicit "sour" or "bitter" taste descriptions as well as "salty" (McBurney and Shick, '71). During development, $\mathrm{NH}_{4} \mathrm{Cl}$ and $\mathrm{KCl}$ may initially interact with "sour" receptor components, and later with "sour" and "salty."

\section{Ultrastructural changes in taste buds}

As well as proposed changes in taste bud cell membranes, ultrastructural alterations may relate to the developing taste response. Nerve endings are present in very young fetal taste buds (80-90 days of gestation) but we do not know whether they change in content, distribution, and/or number during development. The quantity and chemical character of the dense substance in the taste pit also merits further study, since chemicals apparently diffuse through this substance to reach taste bud cell membranes. We did not observe this substance in the youngest fetuses. Histochemically the dense substance has been described as a mucopolysaccharide in other taste buds (Scalzi, '67), but its functional importance is not known. Finally, although at least two cell types are present in young fetal taste buds, additional types might be added and relative proportions of types might change developmentally.

\section{Developmental changes, taste bud turnover, and regeneration studies}

Changes in taste responses during development were predicted over 20 years ago by Beidler ('61). In discussing the continuing process of taste bud cell turnover during adult life (Beidler and Smallman, '65). Beidler proposed that newly formed taste cells might respond better to certain stimuli than older taste cells. He thought his hypothesis could be tested by recording from a regenerating taste nerve as the fibers reinnervate the tongue epithelium and new taste buds form. This idea was studied during taste bud regeneration in gerbils and it was concluded that most "young" cells respond in a manner similar to "old" taste cells (Cheal et al., '77). However, it was also noted that $\mathrm{NH}_{4} \mathrm{Cl}$ was a more effective stimulus than $\mathrm{NaCl}$ in the earliest period of regeneration, although the greater effectiveness of $\mathrm{NH}_{4} \mathrm{Cl}$ was not invariably found. Since nerve crush was used in the study, both old and new receptors could have been present in some animals and thereby yielded the variable results.

The processes of initial taste bud development, of taste bud cell replacement through turnover in adult life, and of 
taste bud regeneration after nerve section and regrowth should not, in any event, be presumed to involve similar mechanisms. In another chemosensory system, the olfactory sense, neural responses from receptors that have newly differentiated after nerve section in salamanders are similar to those from control receptors (Simmons and Getchell, '81). Yet, other investigators maintain that olfactory receptor neurons in fetal rats respond very differently to odorants than receptors in adult animals (Gesteland et al., '80). These contradictory results may relate to species or methodological differences, or to differences in the processes of development and regeneration.

Our developmental studies of the taste system in sheep and rat (Hill et al., '82) certainly suggest that Beidler's original proposition relating taste bud age to response characteristics may be correct. For example, newly formed taste cells might be more responsive to $\mathrm{NH}_{4}{ }^{+}$, relative to $\mathrm{Na}^{+}$. In older cells, the reverse might occur. In young fetuses, when more taste buds are being added in each fungiform papilla (Bradley and Mistretta, '72, '73), a predominance of young, highly $\mathrm{NH}_{4}{ }^{+}$-responsive cells might be present. In older animals, as fewer new taste buds are added, young and old cells could be maintained in balanced proportion in established taste buds by the turnover process. Therefore the taste system would be about equally responsive to $\mathrm{NH}_{4}{ }^{+}$and $\mathrm{Na}^{+}$, as we observed in adults.

Comparison of developmental changes in peripheral and central taste responses in sheep

The developmental changes that we have observed in the periphery are similar to those in the central taste system; at both levels $\mathrm{NaCl}$ and $\mathrm{LiCl}$ become progressively more effective stimuli, when compared to $\mathrm{NH}_{4} \mathrm{Cl}$ or $\mathrm{KCl}$. However, at an age when small-magnitude peripheral nerve responses to $\mathrm{NaCl}$ and $\mathrm{LiCl}$ are obtained (i.e., 108114 days of gestation), no responses to these salts were observed in taste neurons in the medulla (Bradley and Mistretta, '80; Mistretta and Bradley, '78). Later in gestation, from 114 days to the end of term, fetal medullary neurons were progressively more likely to respond to $\mathrm{NaCl}$ and $\mathrm{LiCl}$ (Bradley and Mistretta, '80). All cells at all ages responded during stimulation of the tongue with $\mathrm{NH}_{4} \mathrm{Cl}$ and $\mathrm{KCl}$.

Since no responses to $\mathrm{NaCl}$ or $\mathrm{LiCl}$ are obtained centrally at an age when small responses are obtained peripherally, the inability of the early fetal central taste system to respond to these salts must relate to factors at the synapse between first-order afferents and second-order cells. Synapses in the central taste pathway may be too inefficient for transmission of low-magnitude responses in young fetuses.

\section{Relation to human taste system}

It is interesting to compare development of the sheep gustatory sense with that of the human. Human taste buds appear during early fetal life and mature structurally in utero (Bradley and Stern, '67), as they do in sheep. Since the time course of structural development is similar in sheep and humans, functional development may also follow a similar sequence. Therefore, postnatal changes in taste function would be occurring in human infants. Several experiments demonstrate that the human gustatory sense is functional at birth (Desor et al., '73; Steiner, '79) and some studies report that taste preferences and aversions change after birth, in childhood and adolescence (Desor et al., '77). Our studies demonstrate that a changing neural substrate underlies taste function. The developmental changes are not only a prenatal phenomenon, but also continue for much of postnatal life. This altering neural substrate provides a basis for interactions between the developing taste system and internal physiological or external environmental influences (Mistretta, '81). Through such interactions taste preferences and aversions may be acquired and modified.

\section{ACKNOWLEDGMENTS}

This research was supported by N.S.F. grant BNS 80 15737 to C.M.M, and R.M.B., and by N.I.H., N.I.D.R. research career development award \#DE00066 to C.M.M. We thank Drs. Thomas V. Getchell and David L. Hill for critical comments on drafts of the manuscript.

\section{LITERATURE CITED}

Beidler, L.M. (1953) Properties of chemoreceptors of tongue of rat. J. Neurophysiol. 16:595-607.

Beidler, L.M. (1961) Taste receptor stimulation. Prog. Biophys. Biophys. Chem. 12:107-151.

Beidler, L.M. (1967) Anion influences in taste receptor response. In T. Hayashi (ed): Olfaction and Taste II. Oxford: Pergamon Press, pp. 509-534.

Beidler, L.M., I.Y. Fishman, and C.W. Hardiman (1955) Species differences in taste responses. Am. I. Physiol. 181:235-239.

Beidler, L.M., and G.W. Gross (1971) The nature of taste receptor sites. In W.D. Neff (ed): Contributions to Sensory Physiology, Vol. 5. New York: Academic Press, pp. 97-127.

Beidler, L.M., and R.L. Smallman (1965) Renewal of cells within taste buds. J. Cell. Biol. 27:263-272.

Bradley, R.M., and C.M. Mistretta (1972) The morphological and functional development of fetal gustatory receptors. In N. Emmelin and Y. Zotterman (eds): Oral Physiology. Oxford: Pergamon Press, pp. 239253.

Bradley, R.M., and C.M. Mistretta (1973) The gustatory sense in foetal sheep during the last third of gestation. J. Physiol. 231:271-282.

Bradley, R.M., and C.M. Mistretta (1980) Developmental changes in neurophysiological taste responses from the medulla in sheep. Brain Res. 191: 21-34.

Bradley, R.M., C.M. Mistretta, and S.D. Lee (1980) Ultrastructural changes in developing taste buds accompany functional changes. Neurosci. Abstr. 6:640.

Bradley, R.M., and I.B. Stern (1967) The development of the human taste bud during the foetal period. J. Anat. 101:743-752.

Brand, J.G., and D.L. Bayley (1980) Peripheral mechanisms in salty taste reception. In M.R. Kare, M.J. Fregly, and R.A. Bernard (eds): Biological and Behavioral Aspects of Salt Intake. New York: Academic Press, pp. 289-298.

Cagan, R.H., and M.R. Kare (1981) Biochemistry of Taste and Olfaction. New York: Academic Press.

Cheal, M., W.P. Dickey, L.B. Jones, and B. Oakley (1977) Taste fiber responses during reinnervation of fungiform papillae. J. Comp. Neurol. 172:627-646.

DeSimone, J.A., and G.L. Heck (1980) An analysis of the effects of stimulus transport and membrane charge on the salt, acid and water-response of mammals. Chem. Senses 5:295-316.

DeSimone, J.A., and S. Price (1976) A model for the stimulation of taste receptor cells by salt. Biophys. J. 16:869-881.

DeSimone, J.A., G.L. Heck, and S.K. DeSimone (1981) Active ion transport in dog tongue: A possible role in taste. Science 214:1039-1041.

Desor, J., O. Maller, and L.A. Greene (1977) Preference for sweet in humans; Infants, children and adults. In J.M. Weiffenbach (ed): Taste and Development. The Genesis of Sweet Preference. Maryland: U.S. Dept. H.E.W. Publication No. (NIH) 77-1068, pp. 161-172.

Desor, J., O. Maller, and R. Turner (1973) Taste in acceptance of sugars by human infants. J. Comp. Physiol. Psychol. 84:496-501.

Dethier, V.G. (1977) The taste of salt. Am. Sci. 65:744-751.

Diamond, J.M., and E.M. Wright (1969) Biological membranes: The physi- 
cal basis of ion and nonelectrolyte selectivity. Annu. Rev. Physiol. 31 : $581-646$.

Farbman, A.I. (1965a) Fine structure of taste bud. J. Ultrastruct. Res. 12 : 328-350.

Farbman, A.I. (1965b) Electron microscope study of the developing taste bud in rat fungiform papilla. Dev. Biol. 11:110-135.

Ferrell, M.F., C.M. Mistretta, and R.M. Bradley (1981) Development of chorda tympani taste responses in rat. J. Comp. Neurol. 198:37-44.

Gesteland, R.C., R.A. Yancey, R.G. Mair, G.D. Adamek, and A.I. Farbman (1980) Ontogeny of olfactory receptor specificity. In H. van der Starre (ed): Olfaction and Taste VII. London: IRL, pp. 143-146.

Halpern, B.P., and L.A. Marowitz (1973) Taste responses to lick-duration stimuli. Brain Res. 57:473-478.

Halpern, B.P., and D.N. Tapper (1971) Taste stimuli: Quality coding time. Science 171:1256-1258.

Hill, D.L., and C.R. Almli (1980) Ontogeny of chorda tympani nerve responses to gustatory stimuli in the rat. Brain Res. 197:27-38.

Hill, D.L., R.M. Bradley, and C.M. Mistretta (1981) Central neural taste responses in prepubertal and adult rats. Neurosci. Abstr 7:537.

Hill, D.L., C.M. Mistretta, and R.M. Bradley (1982) Developmental changes in taste response characteristics of rat single chorda tympani fibers. J. Neurosci. 2:782-790.

Jahnke, K., and P. Bauer (1979) Freeze-fracture study of taste bud pores in the foliate papillae of the rabbit. Cell Tissue Res. 200:245-256.

Kamo, N., M. Miyake, K. Kurihara, and Y. Kobatake (1974) Physicochemical studies of taste reception. II. Potential induced by salt stimuli. Biochem. Biophys. Acta 367:11-23.

Kare, M.R., M.J. Fregly, and R.A. Bernard (eds) (1980) Biological and Behavioral Aspects of Salt Intake. New York: Academic Press.

Kitchell, R.L. (1963) Comparative anatomical and physiological studies of gustatory mechanisms. In Y. Zotterman (ed): Olfaction and Taste, Vol. I. Werner-Gren Center Internatl. Sympos. Series. Oxford: Pergamon Press, p. 235-255.

Macknight, D.C., and J.P. Leader (eds) (1981) Epithelial Ion and Water Transport. New York: Raven Press.

Marowitz, L.A., and B.P. Halpern (1977) Gustatory neural response of the chorda tympani to lick-duration stimuli. Chem. Senses Flavor 2:457485 .
McBurney, D.H., and T.R. Shick (1971) Taste and water taste of twentysix compounds for man. Percept. Psychophysiol. 10:249-252.

Mistretta, C.M. (1981) Neurophysiological and anatomical aspects of taste development. In R.N. Aslin, J.R. Alberts, and M.R. Peterson (eds): Development of Perception, Vol. I. New York: Academic Press, pp. 433455 ,

Mistretta, C.M. (1982) A neural basis for developing taste perception. In J.E. Steiner and J.R. Ganchrow (eds): Determination of Behaviour by Chemical Stimuli. London: IRL Press, pp. 27-36.

Mistretta, C.M., and R.M. Bradley (1977) Maturation of CNS taste responses during fetal development. Ann. Rech. Vet, 8:495-496.

Mistretta, C.M., and R.M. Bradley $(1978)$ Taste responses in sheep medulla: Changes during development. Science 202:535-537.

Mollgard, K., and J. Rostgaard (1981) Morphologic aspects of transepithelial transport with special reference to the endoplasmic reticulum. In S.G. Schultz (ed): Ion Transport by Epithelia. New York: Raven Press, pp. 209-231.

Mooser, G. (1980) Membrane transitions in taste receptor cell activation by sodium salts. In M.R. Kare, M.J. Fregly, and R.A. Bernard (eds): Biological and Behavioral Aspects of Salt Intake. New York: Academic Press, pp. 275-288.

Murray, R.G. (1973) The ultrastructure of taste buds. In I. Friedmann (ed): The Ultrastructure of Sensory Organs. New York: Elsevier, pp. 1-81.

Sato, R., and L.M. Beidler (1975) Membrane resistance change of the frog taste cells in response to water and NaCl. J. Gen. Physiol. 66:735-763.

Sato, T., K. Sugimoto, and Y. Okada (1982) Ionic basis of receptor potential in frog taste cell in response to salt stimuli. Jpn. J. Physiol. 32:459-462.

Scalzi, H.A. (1967) The cytoarchitecture of gustatory receptors from the rabbit foliate papillae. Z. Zellforsch. Mikrosk. Anat. 80:413-435.

Simmons, P.A., and T.V. Getchell (1981) Physiological activity of newly differentiated olfactory receptor neurons correlated with morphological recovery from olfactory nerve section in the salamander. J. Neurophysiol. 45:529-549.

Smith, D.V., and S.L. Bealer (1975) Sensitivity of the rat gustatory system to the rate of stimulus onset. Physiol. Behav. 15:303-314.

Steiner, J.E. (1979) Human facial expressions in response to taste and smell stimulation. Adv. Child Dev. Behav. 13:257-295. 